\title{
Concepts of EFL Reading among Taiwanese College Students of Low Reading Proficiency
}

\author{
Hui-Lung Chia \\ Chung-Shan Medical \& Dental College
}

\section{Hui-Uen Chia}

Wu-Feng Junior College of Technology \& Commerce

This study is an empirical and descriptive exploration of EFL. reading concepts held by Taiwanese college students of low reading proficiency. Fifty subjects were selected accarding to their reading comprehension scores on the Secondary Level English Proficiency Test and were scheduled for interviews. Forty-five subjects took part in the interviews and their responses were tape-recorded, transcribed, and analyzed both qualitatively and quantitatively. The results indicate that there are certain concepts about EFL, reading which are shared by the subjects. Generally they showed little awareness of independent, internally generated repair strategies, tended to process EFL reading at word level in a rather analytical fashion, and mainly viewed EFL reading as a language learning exercise, Several strategies reflecting this restricted view of reading are identified. The paper concludes with a discussion of pedagogical implications.

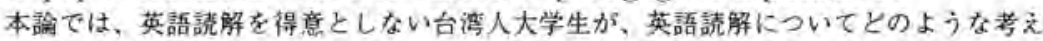

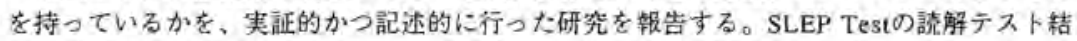
果に基ついて50名の被験者を邀び、このうち45名に詨して個別インタピューを行った。イ

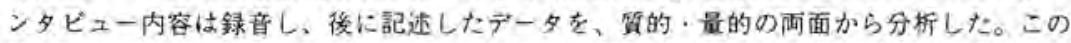
結果、被䮴者が英語読解について、特徽的な考文方を持っていることが明らかになった。

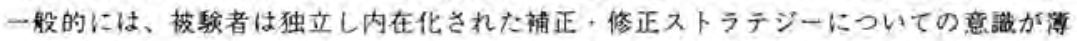
く、䛨解を、単語レベルの分析的な作莱、教室における言語学習練習と考えている。この

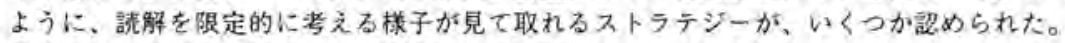
最後に、この結果を踏まえて、珫解教育への示睃について述へる。

Teaching students to read English is a major goal of high school English education in many Asian countries, such as Taiwan, Japan and Korea, where students have to take written English tests for college entrance examinations. Some students are successful in learning to read English yet others remain at a low proficiency level throughout 
their school years. However, poor readers are found not only among EFL learners but also among students reading in their native language (L1). Many adult readers in the United States, for example, have been diagnosed as failing to develop fifth grade level reading skills (Micklos, 1990). These students, often termed "low literate readers"(Gambrell \& Heathington, 1981), have inspired extensive research investigating the reasons for their unsuccessful learning.

One research focus deals with students' concepts about the nature and function of reading. Researchers in metacognition (Baker \& Brown, 1984; Jacobs \& Paris, 1987) have demonstrated that learners' knowledge about what constitutes learning coordinates and directs their thinking and behavior Thus, if readers are aware of what is involved in the reading process and what is necessary to read effectively, then it is possible for them to take steps to meet the demands of a reading situation. On the other hand, if readers are not aware of, or have misconceptions about, the complexity of a reading task, then they cannot take appropriate action. Studies of poor readers which reveal their metacognitive awareness of the reading process and their use of reading strategies have shed light on some of the reasons for their unsuccessful learning.

\section{L1 Studies of Poor Readers}

Studies of L1 readers have identified several misconceptions about reading which characterize poor readers. They often perceive reading as a decoding process rather than as meaning construction (Fagan, 1988; Gambrell \& Heathington, 1981; Malicky \& Norman, 1989; Poissant, 1994). They also look to external sources such as teachers to resolve their comprehension failure, and are not aware of independent internally generated strategies (Fagan, 1988; Gambrell \& Heathington, 1981). In addition, they often consider reading mainly as memorizing rather than as understanding meaning (Johnston, 1985).

Another line of L1 research investigating the relationship between students' concepts about reading and their reading achievements has provided further insights into the concepts held by poor readers. Osburn and Maddux (1983) reported that students with vague, meaningless concepts about reading often exhibited lower reading proficiency than those who gave meaningful definitions of reading. Furthermore, poor readers often described reading as the decoding of individual words instead of a process involving thinking and understanding. Similar findings have been reached by other researchers as well (Foley, 1984; Lesesne, 1991; O'Sullivan, 1992). 
Recently $\mathrm{L} 1$ researchers seem to have shifted their attention from the characteristics of good and poor readers to the connections between students' concepts and different instructional settings (Burns-Paterson, 1991; Freppon, 1995; Reutzel \& Sabey, 1996). However, the results of these studies have often been interpreted in light of previous findings. Furthermore, based on what has been discovered about good and poor readers' reading concepts, $\mathrm{L} 1$ reading research has been conducted to examine the effects of metacognitive training on reading comprehension. Although some studies have not found any facilitating effect for training (Duffy, Roehler, Meloth, Vavrus, Book, Putnam, \& Wesselman, 1986; Jacobs \& Paris, 1987) other studies have found it effective. These studies have illustrated that in classroom settings, poor readers who enhance their awareness of the nature of reading will ultimately become better readers than those who do not (Kinnunen \& Vauras, 1995; Lysynchuk, Pressley, \& Vye, 1990; Nist \& Mealey, 1991; for reviews of research on metacognitve training in L1 reading, see Rosenshine, Meister \& Chapman, 1996). Thus, the first step in enhancing inefficient readers' awareness is to discover what they believe about the reading process.

\section{Reading Concepts in Second/Foreign Language Learners}

Similarly, English as a second/foreign language (ESL/EFL) reading research has focused attention on metacognitive strategy training to improve students' reading comprehension (Casanave, 1988; Mulling, 1994; Swaffar, Arens, \& Byrnes, 1991). However, the requisite research for such instruction is scarce since little research has been conducted regarding poor readers' concepts about ESL/EFL reading. Two studies have suggested that decoding-oriented concepts correlated with lower performances in reading English in L2 (Carrell, 1989; Devine, 1984). However, these two studies were limited to readers' conceptualization of strategy use, and did not investigate their awareness of other aspects of the reading process, such as the students' notions of the purpose and function of reading, which often provide enlightening insights into their reading behavior, including the use of strategies.

While a vast body of research in L1 reading has found that poor readers have more misconceptions about important characteristics of reading than good readers do, we know very little about metacognitive factors in EFL reading. Without the requisite research, we only have the assumption that instruction in metacognitive training would be beneficial in that case as well. 


\section{Research Focus}

The present study was undertaken to empirically explore concepts about English reading held by low reading proficiency Taiwanese EFL. readers, aiming to add critical information to our limited knowledge base about EFL readers. Only with a better understanding of what poor EFL readers think about reading can a teacher be adequately prepared to meet their needs.

\section{Method}

\section{Subjects}

All freshmen $(\mathrm{N}=805)$ in Chung Shan Medical \& Dental College, Taichung, Taiwan, were administered the Secondary Level English Proficiency Test (SLEP, a standardized test published by the Educational Testing Service) as an English placement test. Fifty students were then selected on the basis of their reading comprehension scores. These were the bottom-ranked students $(29 \%$ and below according to the percentile ranks for SLEP scores) and therefore represented the low reading proficiency group. The 50 subjects were scheduled for individual interviews, and eventually 45 took part in the interviews.

\section{Interview Procedures}

Each subject was individually interviewed in her/his native language, Mandarin Chinese, by one of the researchers using eight questions adapted from the Burke Reading Interview (cited in Osburn \& Maddux, 1983). The general question "What is reading?" was positioned last to "allow the students to warm up to the subject of reading and thus minimize the likelihood of an 'I don't know' response." (Canney \& Winograd, 1979 , p. 24). The interviews were tape-recorded and were transcribed for analysis.

\section{Data Analysis}

The subjects' responses were analyzed by the technique used in Reutzel and Sabey (1996), a systematic and interpretive way to analyze verbal responses to interview questions both qualitatively and quantitatively The data was analyzed through processes of construction and enumeration (Lincoln \& Guba, 1985). Construction in the present study refers to the categorization of verbal responses into interpretive categories. For instance, the following two verbal responses "I often ask my teacher for help when I encounter reading difficulties" and "I usually turn to my 
classmates for help to solve reading problems " can be grouped into the same category labeled "asking someone."

The categorization was conducted using both open coding and axial coding (Stauss \& Corbin, 1990). Open coding is a process whereby the answers to each question in the interview from, for example, the first five students are categorized. As the data analysis progresses, the responses to the same question from the rest of the subjects are grouped into the established categories, or, if necessary, are used to create new categories. The open coding data can be further combined through an axial coding process. In axial coding, related categories are grouped under a more inclusive higher order concept. For example, when analyzing the subjects' responses to a question about what they usually focus on in order to read effectively, a researcher may identify some verbal events categorized as "words," some categorized as "phrases," and some defined as "sentences. The researcher can group these three open categories into a more inclusive category and name it "language unit." This more general category suggests that the subjects are focusing on the language features rather than on the message conveyed by the text. In this way, axial coding results in a reduction of multiple open coding categories to more inclusive axial coding categories, a process which enables the researcher not only to reduce the number of units she/he is working with, but also to discover relationships among the categories.

Enumeration is a process whereby each verbal event within each category is counted. It results in the construction of frequency histograms for responses to each of the interview questions. Here the term "verbal event" refers to a unit consisting of words, phrases or sentences containing a certain significant property shared by the other units in the same category. For example, the learner's comment, "When I confront something that $\mathrm{I}$ don't understand in reading, I often ask my teacher. She is very knowledgeable and always knows the answer." is considered one verbal event. "I usually turn to my classmates for help in solving reading problems." is another verbal event. Both of these share a common characteristic, asking someone for help. Hence, by the process of enumeration, the category "asking someone" has a count of two verbal events.

In the present study, the data was categorized and the percentile frequency of events within each category was computed by the same researcher. Afterwards, the other researcher coded both the categories and percentile frequency counts. If the two researchers did not agree on the categorization of a verbal response, the verbal response was marked. There was a $91 \%$ agreement between the two researchers regarding the 
categorizations of the verbal responses, and all disagreements were resolved through discussion.

\section{Results}

The results of this study will be presented according to the questions asked in the interview.

Interview Question One: Do you think you are a good reader when reading English? Why or why not?

The students' responses to Question One indicate their perception of themselves as EFL readers. A full $96 \%$ answered "No" and only $4 \%$ answered "Yes." Thus the majority of the students did not consider themselves good readers.

The responses to the second part of the question, why students thought they were poor readers, are illustrated in Figure 1.

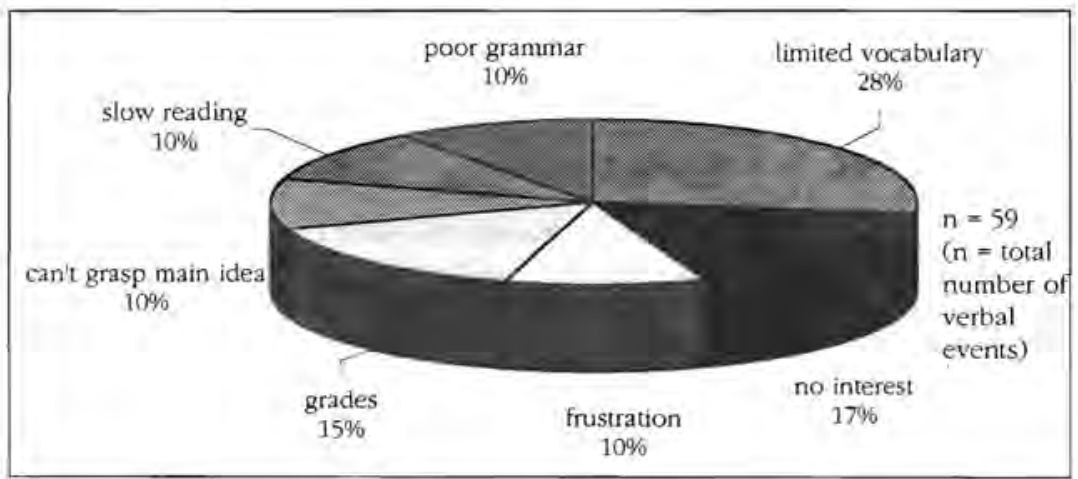

Figure 1: Reasons for Not Being A Good Reader ${ }^{1}$

These results indicate that the students gave limited vocabulary as their primary reason for their perception of themselves as poor EFL readers. Furthermore, examination of the data reveals that psychological factors, including two open coded categories no interest and feeling of frustration, were given as secondary reasons for their negative selfimage. English grades, an external validation, was viewed as the third reason, as shown by the following comment: "My English reading ability is poor because my English grades at school are always very low." 
Finally, the meaning-oriented notion of reading, can't grasp main idea, and the other two categories, slow reading and poor grammar, received equal attention from the subjects.

\section{Interview Question Two: When you are reading in English and come} to something you don't know, what do you do?

Responses to this question reveal how low proficiency EFL readers respond to unknown text elements. As shown in Figure 2, the subjects tended to rely heavily on a dictionary and other external sources to solve problems in reading English, since the open coded categories look it up and ask someone were fayored. Furthermore, an interesting finding is observed regarding the category skip. The subjects viewed this as a "passive" strategy to escape from the difficulties rather than an effective means to deal with comprehension failure. The following statements exemplify passive strategy use:

Student A: When I come to something that I don't understand, I usually feel very frustrated because that happens to me very often. So, 1 will skip it and read the next part.

Researcher: Would you skip it even if it is a key point in the passage?

Student A: Since I don't understand it, I cannot tell if it is important or not. Therefore, I usually just give up and read on.

Finally, the frequency counts of events in each category, except for those in look it up and ask someone, are very low, illustrating that most of the students know very little about repair strategies.

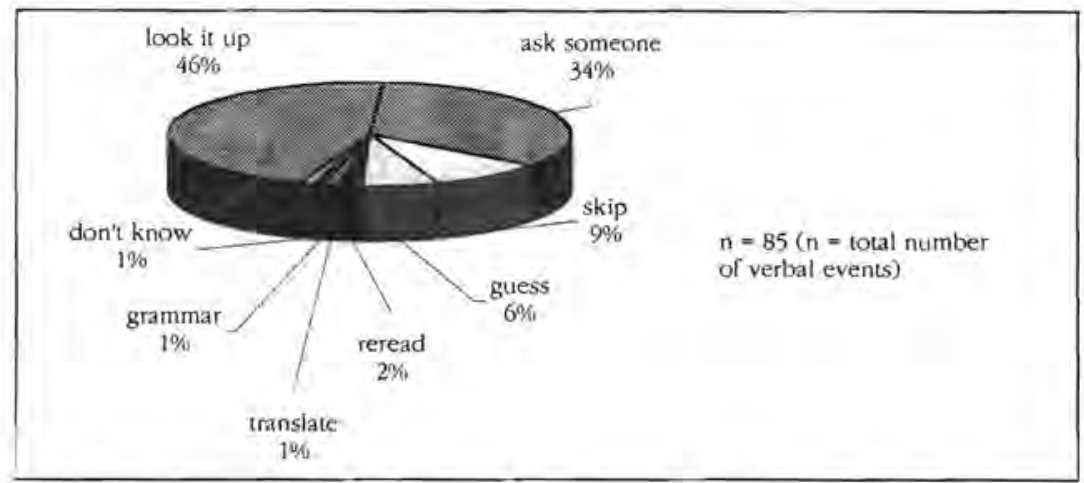


Interview Question Three: When you read in English, what do you usually focus on in order to read effectively?

The third question was designed to elicit students' viewpoints about effective strategies. Four categories were produced by axial coding (see Figure 3).

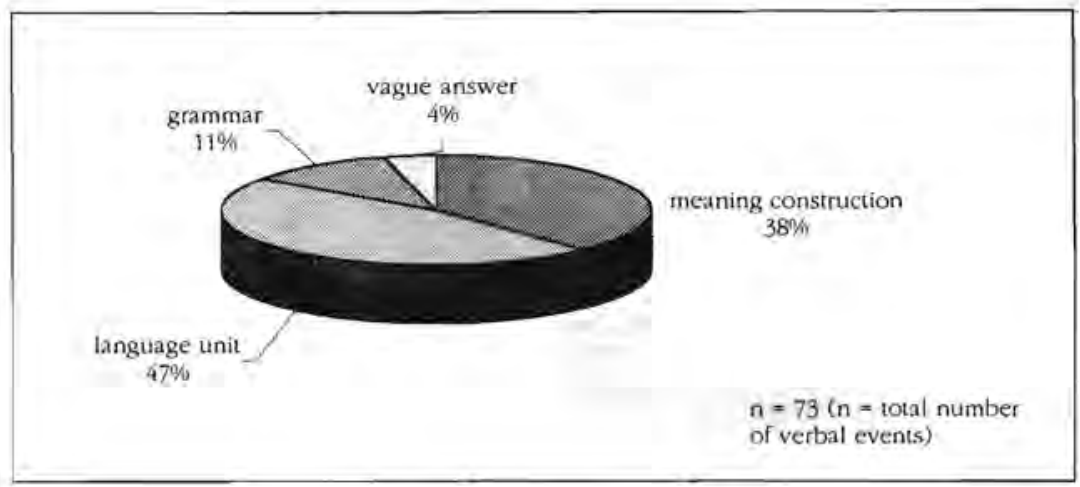

Figure 3: Items to Focus on for Effective Reading

The highest proportion of the responses was allocated to the axial coding category language unit, which includes the open coding categories words, phrases, and sentences. This result indicates that the subjects were inclined to process reading analytically. When they read they paid a great deal of attention to individual words, phrases, and sentences. The following student comments from the interviews illustrate the responses within this category:

I would like to figure out what each word means.

You need to understand what each sentence says, then you will know what the entire article is about.

I usually like to read each sentence phrase by phrase, and then I put them all together to figure out the sentence.

After language unit, meaning construction strategies were prevalent. These include the open categories main ideas, topic sentences, title, pictures, and bold words. Furthermore, the students also considered that analyzing sentence structure grammatically, such as identifying subjects and verbs, facilitated reading comprehension. 
Interview Question Four: Who is a good English reader that you know? What makes her/him a good reader?

The responses to this question indicates the subjects' perceptions of the characteristics a good EFL reader possesses (see Figure 4). Interestingly, the results shows that although more variations are yielded, the attributes appear similar to those which the subjects felt that they lacked (Figure 1), thus leading to their perception of themselves as poor EFL readers.

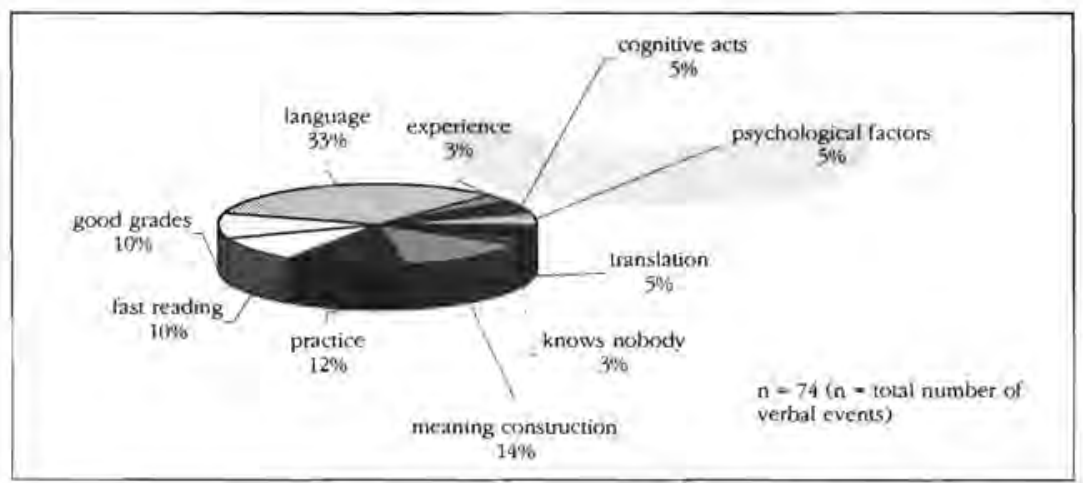

Figure 4: Characteristics of a Good English Reader

The first similarity is observed in the most dominant response, language makes good readers. The language category itself includes four open categories: good grammar, speak fluently, write better, and large vocabulary, the latter carrying the most weight. Among these the students mentioned grammar and vocabulary as two of the reasons why they did not consider themselves to be good EFL readers. Moreover, although much less prominent than language, four attributes were considered almost equally important for effective reading: meaning construction, good grades, fast reading and practice. Finally, psychological factors, including interest, were again mentioned here.

Three of the subjects answered that they did not know any good readers of English because, as one noted, "Birds of a feather flock together, so I don't know any good English reader." 
Interview Question Five: Do you think that ever comes to something she/he doesn't know when reading English? If yes, what do you think she/he does?

Like Question Four, Question Five investigates the students' perceptions of the skilled English reader they listed in Question Four by asking whether this person ever meets difficulties and, if so, what action would she/he take. Eighty seven percent of the students gave a "yes" answer, believing that their model reader of English would continue to encounter unknown text and would have to refine her/his reading skills.

The open coding responses to the second part of Question Five assessed the strategies that the poor readers thought the skilled readers would use (Figure 5). The subjects' estimates of what skilled readers would do were quite similar to their own very limited repair strategies for attacking difficulties in reading (Figure 2).

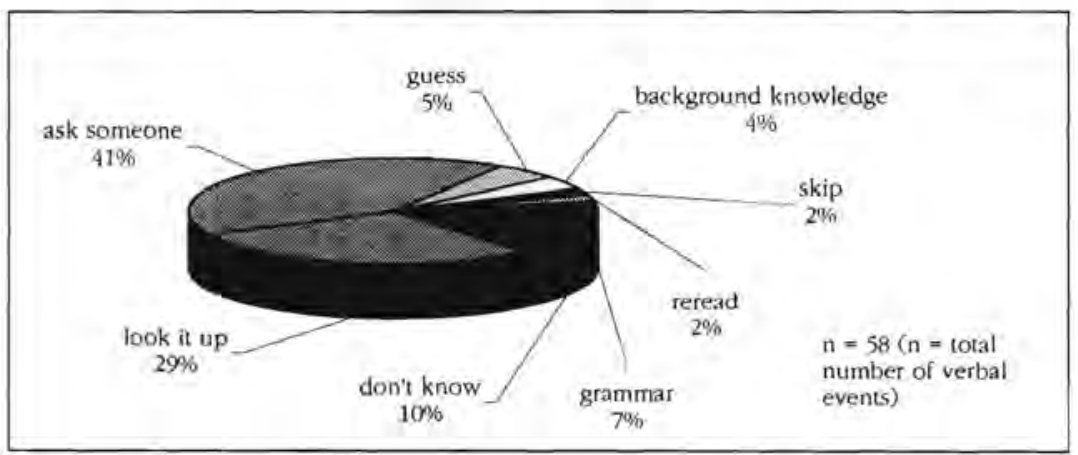

Figure 5: "Good Reader" Strategies for Reading Difficulties

Of the eight categories shown in Figure 5, seven are identical to those in Figure 2. Furthermore, look it up and ask someone continue to be the most prominent reading strategies. Finally, the percentile frequency counts of events in the categories other than look it up, ask someone and don't know, remain very low, ranging from $2 \%$ to $7 \%$.

Interview Question Six: If you know someone who is having trouble reading in English, what would you suggest that she/be should do?

Axial coding categories of the interview responses (Figure 6) appear similar to those mentioned in Figure 4 showing the students' perceived image of good readers. It seems that students continue to draw upon 
the same set of strategies they believe good readers would use to help other readers in trouble. Again, a very strong preference for the category language is evident here. The category itself consists of four open categories, large vocabulary, grammar, listening to English, and speaking English. It is notable that subjects particularly attributed successful reading to large vocabulary.

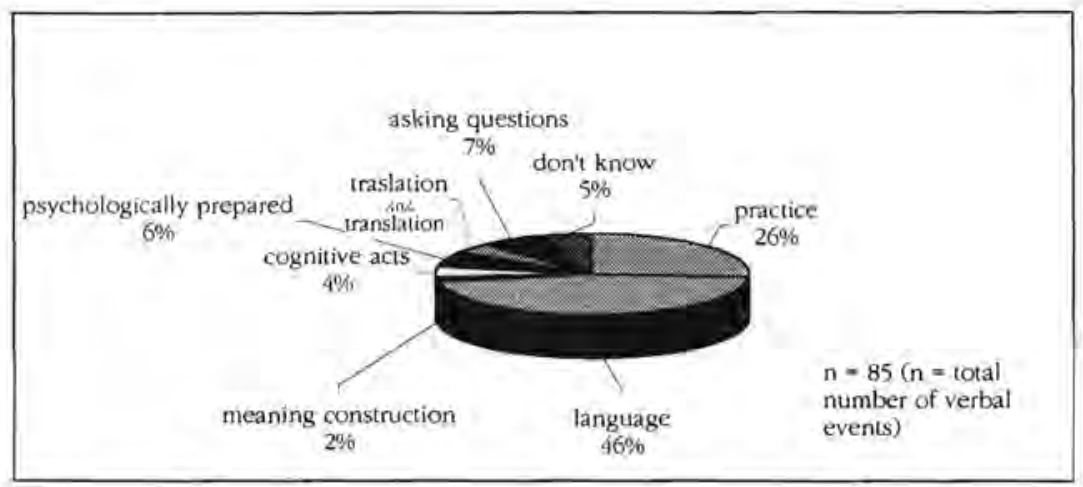

Figure 6: Recommended Strategies for Reading Difficulties

Interview Question Seven: How do you think a teacher would try to belp someone who is having trouble with her/his English reading?

The students' responses to this question are of interest because they offer insights into what poor English readers expect from their teachers. Although some variations are observed, the axial coding categories shown in Figure 7 are similar to those presented in Figures 4 and 6. Thus, students would like their teachers to teach the strategies they believe good readers use for reading success. Throughout the three related interview questions, six categories were repeatedly mentioned: meaning construction, language, practice, psychological factors, translation and cognitive acts, the last indicated by responses such as "study hard" and "listen to the teacher attentively in class." Among them, language remains the most prominent category; here particular attention is given to vocabulary and grammar. 


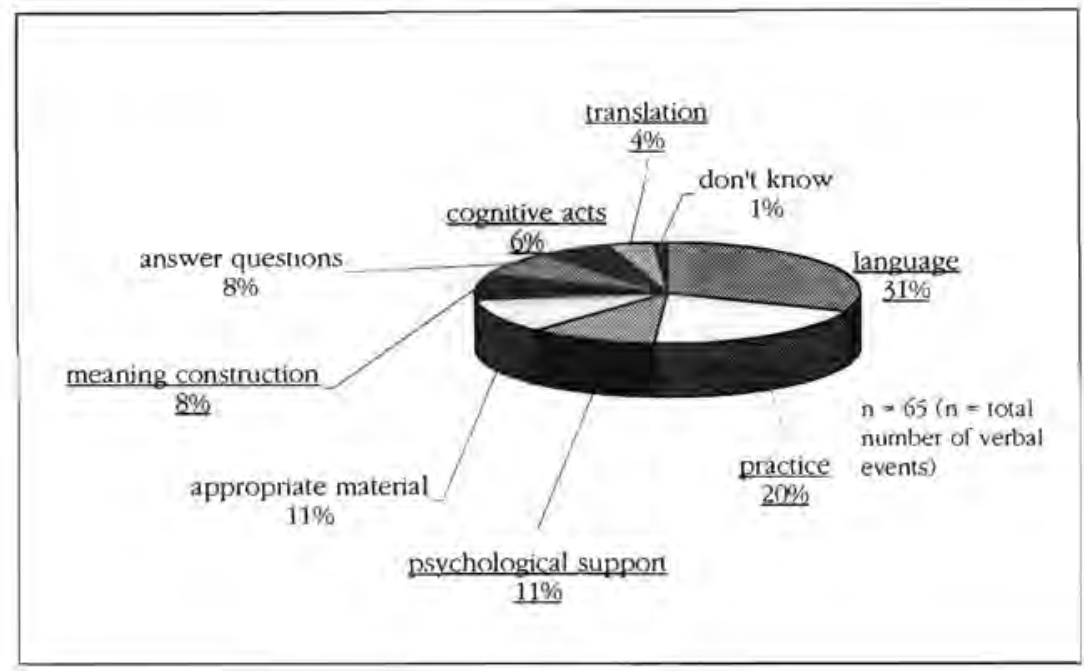

Figure 7: Teacher Assistance for Reading Difficulties

Interview Question Eight: What is English reading?

The final question investigates students' perceptions of EFL reading in general. The open categories resulting from the responses (Figure 8) indicate that the subjects were apt to define EFL reading in terms of the function of reading, the reading process, and their negative emotion toward reading. The functional viewpoint of English reading was the most favored concept, especially the viewpoint that EFL reading is identical to other language learning activities which students perform in order to advance their English proficiency. In addition, some of the subjects responded that reading had another function, that readers could gain new knowledge. After the functional view came the belief that EFL. reading is a process of understanding overall meaning and/or individual words, and ranslating English into Chinese. Regarding their feelings toward EFL reading, none of the subjects associated reading with positive emotions but rather with negative and depressing feelings, as shown in the following comments:

Reading is boring.

I often feel frustrated.

English reading is equal to failure for me. 


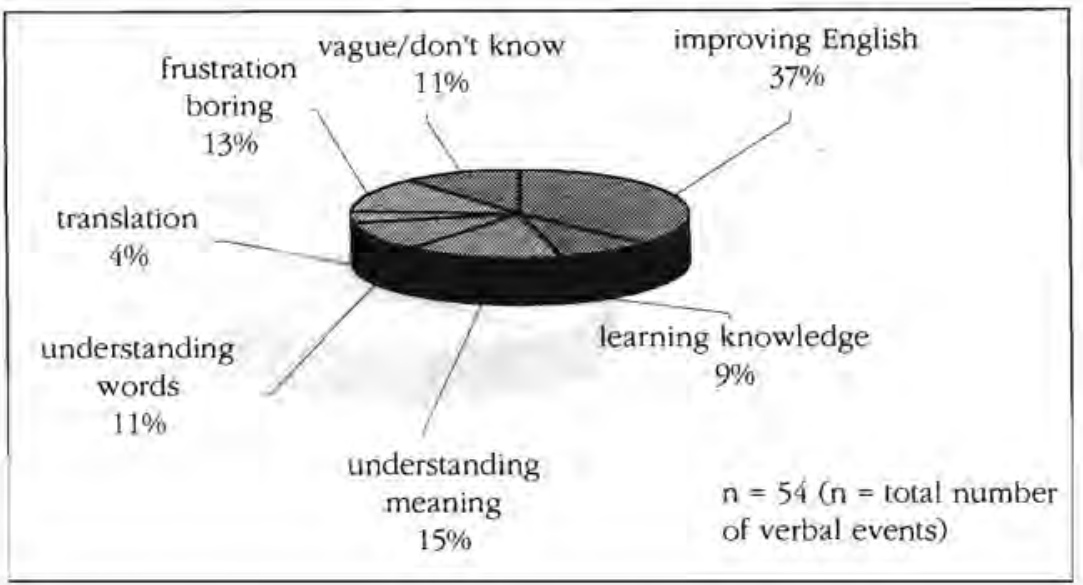

Figure 8: General Concepts of English Reading

\section{Discussion}

This limited study investigated concepts of EFL reading held by 45 Taiwanese college students of low reading proficiency and yielded findings concerning their views of effective reading strategies, the features which characterize repair reading, and their general concepts of EFL reading.

We begin by discussing the strategies that the subjects believe can solve their reading difficulties. Two dominant repair strategies were identified: look it up and ask someone, strategies often adopted by poor L1 readers as well (Gambrell \& Heathington, 1981). The subjects in this study apparently believe that these two approaches have the greatest utility for dealing with English reading problems. However the subjects possessed very little awareness of other repair strategies, as indicated by the low frequency counts of verbal events within other categories. Even worse, they seemed to regard the other strategies as passive approaches to escape from a reading dilemma rather than as an effective way to solve comprehension failure.

Their heavy reliance on the strategy look it up indicates that they tended to consider reading difficulty mainly as confronting unknown words. This is to be expected if their stated characteristics of effective reading are considered. For this group lange vocabulary leads to successful reading. Consequently, it is reasonable for them to believe that unsuccessful reading is often caused by unknown vocabulary. Looking up unknown vocabulary in a dictionary inevitably becomes one of their most powerful weapons to tackle problematic elements in reading. 
As for what comprises effective reading, six characteristics were mentioned: language, meaning-construction, practice, psychological supports, cognitive acts, and translation. It seems that the subjects were aware of meaning-driven strategies. However, the percentile frequency counts in this category were overwhelmingly lower than those in the category language, suggesting that the subjects greatly preferred analytical approaches to holistic ones, a finding in line with studies of poor L1 readers. Within the category language, large vocabulary received the greatest emphasis. This concept could logically motivate the students' preference for look it up as a repair strategy, as discussed above. In addition to large vocabulary, grammar was also repeatedly mentioned throughout the interviews. This finding suggests that students often considered EFL reading as a process of decoding individual words and analyzing the grammatical relationship of each word to other components in the sentence.

The subjects' perception of the important role of vocabulary for good reading and their analytical approach toward reading are supported by the results of other studies endorsing interactive models of reading and threshold hypotheses. Researchers who advocate an interactive reading approach have argued that both top-down and bottom-up processing take place during fluent reading (Haynes, 1993; Smith, 1994). Reading is suggested to be a process composed of hierarchical components including word recognition, phonetic decoding, applying background knowledge, ind making predictions. Poor $\mathrm{L} 2$ readers often do not have sufficient vocabulary knowledge, and thus direct most of their attention to word recognition or decoding tasks and consequently fail to direct adequate attention to global components (Coady, 1993; Huckin, 1986). In other words, tackling words is usually the main concern of poor readers when they read. Further support comes from studies on threshold hypotheses which suggest that effective transfer of reading skills from L1 to L2 is possible only after a certain threshold level of L2 proficiency has been reached. Research indicates that $\mathrm{L} 2$ learners who have not achieved a threshold vocabulary base can not employ the higher level processing skills and strategies which they have already acquired in their L1 (Brisbois, 1995; Bernhardt \& Kamil, 1995). Thus sub-threshold readers often retreat to basic word decoding strategies when they read in the L2.

The presence of an analytical decoding approach is further supported by the EFL students' concept that English reading is mainly a language exercise to improve their English proficiency. This view might strengthen their belief that when reading in English, they should concentrate on linguistic features such as words and sentence structure rather than on the meaning conveyed. Such a restricted view of English reading may originate from the EFL learning environment in which they received 
their high school education. English is a foreign language in most Asian countries, including Taiwan and Japan, and high school students are seldom required to read it outside of the classroom. If English reading teachers over-emphasize linguistic components such as vocabulary and grammar, students may fail to acquire the communicative aspects involved in English reading.

The subjects ${ }^{i}$ general viewpoint that English reading is language practice also sheds light on the finding that none of them associated English reading with pleasure but rather found it frustrating and boring. English reading might be burdensome and even painful if the results are low English grades. The negative impact of low English grades on the subjects' concepts of EFL reading was further indicated by their reference to grades as one of the major reasons for their view of themselves as poor EFL readers.

Finally, their consistent mention of two other properties of effective reading, cognitive acts and translation, are of great interest although the percentile counts were not high. Since the students often defined reading as language learning practice, it is reasonable for them to think that reading requires cognitive effort. Their preference for translation might also be related to their learning experiences in high school. In order to teach a group of students who speak the same language as the teacher, it is sometimes be effective for the teacher to conduct instruction in the shared mother tongue (L1). Whether L1 use facilitates EFL teaching is a controversial issue and is unrelated to this study. However, over-reliance on this strategy may be detrimental to the students' EFL reading ability.

In summary, the results of the present study reveal several concepts about EFL reading held by Tawanese college students of low reading proficiency. Generally, they showed little awareness of independent, internally generated repair strategies, tended to process EFL reading at word level in a rather analytical fashion, and mainly viewed EFL reading as a language learning exercise.

\section{Pedagogical Implications}

The present study explores concepts of reading acquired by poor EFL readers, aiming to identify teaching methods which would help low level students become better readers. To achieve this goal, several teaching approaches will be proposed in this section.

First, the subjects' limited repertoire of repair strategies indicates that it would be helpful to deliver instruction to enhance their awareness of the reading process. $\mathrm{L} 1$ readers have been shown to benefit from explicit instruction on metacognitive training, so perhaps EFL readers would 
also benefit. Several approaches designed to promote readers' metacognitive awareness might be effective, such as reciprocal teaching (Palinscar \& Brown, 1986), Question-Answer Relationships (QARs; see Raphael, 1982), and self-questioning (Sanacore, 1984). These approaches provide students with simple guides to help them monitor their reading comprehension and select appropriate repair strategies when comprehension fails.

Furthermore, instruction on holistic reading skills could also be beneficial since the subjects demonstrated an over-reliance on analytical strategies. Several top-down approaches such as previewing, predicting, and formulating potential questions (Williams, 1987) have been shown to help students direct their attention to the ideas presented in the text. In addition, instruction on vocabulary learning seems to be essential because the role of vocabulary in reading was greatly emphasized by the subjects, who might not have achieved a threshold vocabulary base, as discussed above. Such instruction should strengthen students' abilities to handle unfamiliar words, for example by teaching them to guess word meanings from contextual clues and to enhance their vocabulary learning strategies through various mnemonic devices (McCarthy, 1990; Hatch \& Brown, 1995).

Finally, since the students mainly perceived English reading as a language exercise, instruction that not only emphasizes the linguistic aspects of a reading passage but also stresses understanding meaning is desirable. In addition to the various top-down approaches mentioned above, post-reading activities such as restructuring text (Alvermann, 1982), answering comprehension questions (Cornish, 1992), and making a summary (Brown \& Day, 1980) would facilitate understanding of the meaning of the text. Moreover, although the necessity to read English for communicative purposes outside the classroom is rare in Taiwan and other Asian countries, opportunities to do so are plentiful since there are many English magazines, newspapers, signs/labels, and instruction manuals which accompany imported goods. Teachers can utilize these materials, especially those related to students' interests, for information acquisition purposes.

If teaching is to be effective, measures of students' concepts of reading are essential, as Lesesne (1991) has argued. Teachers who have identified students' inaccurate concepts and ineffective strategy use can plan instruction to meet the needs of the students. The present study has showed that, like L1 poor readers, Taiwanese college students of low reading proficiency held several misconceptions about English reading. However, distinct from L1 readers, some of these concepts seemed to be related to the EFL learning environment. Further research is in 
order to confirm the findings here and to explore other concepts held by poor EFL readers.

Hut-Lung Chia teaches EFL at Chung-Shan Medical \& Dental College, Taiwan. She has published several articles on EFL reading, including empirical research and pedagogical techniques.

Hui-Uen Chia teaches EFL at Wu-Feng Junior College of Technology \& Commerce, Taiwan. Her research interests include ESP and psycholinguistics, especially learning strategies and reading.

\section{Note}

1. The $n$ in Figure 1 and subsequent figures indicates the total number of verbal events. Although there were 45 subjects in the study, $n$ is not always 45 because the subjects often answered the interview questions with more than one verbal response.

\section{References}

Alvermann, D.E. (1982), Restructuring text facilitates written recall of main ideas. Journal of Reading, 25, 754-758.

Baker, L, \& Brown, A.L. (1984). Metacognitive skills and reading. In D. Pearson (Ed), Handbook of Reading Research (pp, 353-394). New York: Longman.

Bernhardt, E., \& Kamil, M. (1995). Interpreting relationships between L1 and L2 reading: Consolidating the linguistic threshold and the linguistic interdependence hypotheses. Applied Linguistics, 16 (1), 15-34.

Brishois, J.E. (1995). Connection between first- and second-language reading. Journal of Reading Bebavior, 27, 565-584.

Brown, A.L., \& Day, J.D. (1980). The development of rules for summarizing texts. Unpublished manuscript, University of Illinois.

Burns-Paterson, A.L. (1991). First and third graders' concepts of reading in different instructional settings. ERIC No. ED 339027.

Canney, G., \& Winograd, P. (1979). Schemata for reading and reading comprehension performance. Technical Report No, 120, Champaign, IL: Center for the Study of Reading.

Carrell, P.L. (1989). Metacognitive awareness and second language reading. Modern Language Journal, 73, 121-134.

Casanave, C. P. (1988). Comprehension monitoring in ESL reading: A neglected essential. TESOL Quarterly, 22, 283-302.

Coady, J. (1993), Research on ESL/EFL vocabulary acquisition: Putting it in context. In T. Huckin, M. Haynes \& J. Coady (Eds.), Second language vocabulary learning (pp. 3-23). Norwood, NJ: Ablex,

Cornish, F. (1992). Foreign language reading comprehension as "externallyguided" thinking. Reading in a Foreign Language, 8 (2), 721-753.

Devine, J. (1984). ESL readers' internalized models of the reading process. In J. Handscombe, R. Orem, \& B. Taylor (Eds.), On TESOL'83 (pp. 95-108). Washington, DC: TESOL. 
Duffy, G., Roehler, L., Meloth, M., Vavrus, L., Book, C., Putnam, J., \& Wesselman, R. (1986). The relationship between explicit verbal explanation during reading skill instruction and student awareness and achievement: A study of reading teacher effects. Reading Research Quarterly, 21, 237-252.

Fagan, W.T. (1988). Concepts of reading and writing among low literate adults. Reading Research and Instruction, 27, 47-60.

Foley, I.M (1984). A study of student viewpoints and reading achievement. Unpublished Master's thesis, University of Buffalo, New York.

Freppon. P.A. (1995). Low-income children's literacy interpretations in a skillbased and a whole language classroom. Journal of Reading Bebavior, 27, 505 533.

Gambrell, L. B., \& Heathington, B.S. (1981). Adult disabled readers metacognitive awareness about reading tasks and strategies. Journal of Reading Bebavior, 13, 215-222.

Hatch, E., \& Brown, C. (1995). Vocabulary, semantics and language education. Cambridge: Cambridge University Press.

Haynes, M (1993). Patterns and perils of guessing in second language reading In T. Huckin, M. Haynes \& J. Coady (Eds.), Second language vocabulary learning (pp. 3-23). Norwood, NJ: Ablex.

Huckin, T. (1986). The use of discourse patterning in foreign-language reading and vocabulary acquisition. DELTA, 2 (1), 57-75.

Jacobs, J.E., \& Paris, S.G. (1987). Children's metacognition about reading: Issues in definition, measurement, and instruction. Educational Psychologist, 22 (3 \& 4), $255-278$.

Johnston, P. H (1985), Understanding reading disability: A case study approach Harvard Educational Review, 55, 153-176.

Kinnunen, R., \& Vauras, M. (1995) Comprehension monitoring and the level of comprehension in high- and low-achieving primary school children's reading. Learning and Instruction, 5 (2), 143-165.

Lesesne, R.S. (1991). A survey of the reading concepts and attitudes of middle school students. Unpublished doctoral dissertation, University of Houston.

Lincoln, Y.S., \& Guba, E.G. (1985). Naturalistic inquiry. Newbury Park, CA: Sage Publications.

Lysynchuk, L., Pressley, M., \& Vye, N. (1990). Reciprocal teaching improves standardized reading-comprehension performance in poor comprehenders. The Elementary School Journal, 90, 469-484.

Malicky, G., \& Norman, C.A. (1989), The reading concepts and strategies of adult nonreaders. Journal of Reading, 33, 198-202.

McCarthy, M. (1990). Vocabulary. Oxford: Oxford University Press

Micklos, J. (1990), NAEP results show little change in reading skills. Reading Today, 7, 1-8.

Mulling, S. (1994). A study of directed comprehension monitoring. College ESL 4 (2), 59-66.

Nist, S, \& Mealey, D. (1991). Teacher-directed comprehension strategies. In R Flippo \& D. Caverly (Eds), Teaching reading and study strategies (pp. 42-85). Newark, DE: International Reading Association. 
Osburn, B., \& Maddux, C.D. (1983). What is reading? Student viewpoints, Journal of Developmental and Remedial Education, 6, 8-9.

O'Sullivan, J. T. (1992). Reading beliefs and reading achievement: A developmental study of students from low income families. ERIC No. ED 354505.

Palinscar, A.S., \& Brown, A.L. (1986). Interactive teaching to promote independent learning from text. The Reading Teacher, 39 (8), 771-777.

Poissant, $\mathrm{H}$. (1994). Assessing and understanding the cognitive and metacognitive perspectives of adults who are poor readers. ERIC No, ED 367958

Raphael, T.E (1982), Question-answering strategies for children. The Reading Teacher, 36 (2), 186-190.

Reutzel, D. R, \& Sabey, B. (1996). Teacher beliefs and children's concepts about reading: Are they related? Reading Research and Instruction, 35 (4), 323-342.

Rosenshine, B., Meister, C., \& Chapman S. (1996). Teaching students to gencrate questions: A review of the intervention studies. Review of Educational Research, 66, 181-221.

Sanacore, J. (1984). Metacognition and the improvement of reading: Some important links, Journal of Reading, 27 (8), 704-712.

Smith, F, (1994). Understanding reading. Mahwah, NJ: Lawrence Erlbaum.

Stauss, A, \& Corbin, J. (1990). Basics of qualitative research: Grounded theory procedures and rechniques. Newbury Park, CA: Sage Publications.

Swaffar, $\mathrm{J}_{3}$, Arens, $\mathrm{K}_{2}$ \& Byrnes, H. (1991). Reading for meaning: An integrated approach to language learning. Englewood Cliffs, NJ: Prentice Hall.

Williams, E. (1987). Classroom reading through activation content-based schemata. Reading in A Foreign Language, 4 (1), 1-7.

(Received February 28, 2000; revised June 26, 2000) 